\title{
Life cycle assessment of cell phones in Brazil based on two reverse logistics scenarios
}

\author{
Daniela da Gama e Silva Volpe Moreira de Moraes $^{\mathrm{a}, \mathrm{b} *}$, \\ Tiago Barreto Rocha ${ }^{\mathrm{c}}$, Marcia Regina Ewald ${ }^{\mathrm{d}}$ \\ a*danielamoreir@hotmail.com, CTl, Brasil \\ b*danielamoreir@hotmail.com, UFSCar, Brasil \\ ctiago.rocha@cti.gov.br, CTl, Brasil \\ dmarcia.ewald@uol.com.br, CTl, Brasi'
}

\begin{abstract}
This article is a result of a cell phone collection obtained at the Center for Information Technology Renato Archer (CTI) under the AMBIENTRONIC Program, an initiative that supports the Brazilian electronic sector in the development of technologies for sustainability. The objective of this article is to assess two reverse logistic scenarios of cell phones using the technique of life-cycle assessment (LCA). The first scenario reflects the current scenario in Brazil, where batteries are recycled in Brazil and the other parts of the phones are outsourced to Europe. The second scenario is a proposal of full treatment in Brazil. The results indicate that the second scenario has a lower potential impact with important reduction of acidification, photochemical oxidation, eutrophication and the use of non-renewable energy. Furthermore, fully implementing reverse logistics in Brazil will enable socioeconomic benefits from the sale of materials and the generation of employment and income.
\end{abstract}

Keywords

Reverse logistics. Life cycle assessment. Analysis of scenarios. Cell phones.

\section{Introduction}

The continuous increase of production and consumption of electronic equipments, also related with its planned obsolescence, has led an increasing concern about their environmentally sound disposal.

The incorrect disposal of these materials generates significant environmental impacts, not only by volume and by the time the electronic waste takes to decompose, but also by the presence of heavy metals in its composition that are harmful to human health and environment.

The increasing of incorrect disposal of electronic equipments over the world has been the main motivation for enacting laws that aim to reduce the content of hazardous substances in electronic waste, as well as give them a proper disposal at the end of the product's life. The European Directives WEEE (waste electrical and electronic equipment) and RoHS (restriction of the use of certain hazardous substances in electrical and electronic equipment) are world references of these legislations.

Following this trend, Brazil established the Brazilian National Policy on Solid Waste, Federal Law $n^{\circ}$ 12.305/2010 (Brasil, 2010a), regulated by Decree $n^{\circ}$ 7.404/2010 (Brasil, 2010b). The Brazilian National Policy on Solid Waste gathers the set of principles, tools, guidelines, goals and actions for the integrated and environmentally sound management of solid waste.

Given this reality, companies are turning to new production processes and sustainable management in order to ensure their survival in times of resource shortages and demand for environmentally friendly products.

Facing the need to support companies in developing and manufacturing environmentally friendly products, the Center for Information Technology 
Renato Archer has created and coordinates the AMBIENTRONIC Program, with support from the Ministry of Science, Technology and Innovation; Ministry of Development, Industry and Foreign Trade and Ministry of Environment.

This article is a result of the analysis of cell phone and accessories waste collected at the Center for Information Technology Renato Archer under the AMBIENTRONIC program with the aims to assess two reverse logistics scenarios of these equipments in Brazil.

\section{Literature review}

\subsection{Environmental regulations for the electrical and electronic sector}

The electronic industry has been increasingly active and aware of environmental issues, regarding the strategic importance of this question in the market and society.

The technological development has resulted in faster obsolescence of electronic equipment and, according to UNEP (Basel Convention, 2012), is generated from 20 million to 50 million tons annually of electronic waste.

The concern about electronic waste incited in a set of specific regulations related to environmental issues. In this section we discuss the regulations related to electronic equipments that have been considered key factors of competitiveness.

A specific initiative considering hazardous waste management is the Basel Convention from 1989, which established guidelines to participating countries on the transport and handling of hazardous waste and was adopted by Brazil in 1993 (Basel Convention, 2012).

During the 1990s ISO has established a committee (TC 207 Technical Committee) with the goal of developing standards (14000 "family") to establish voluntary requirements for companies to manage their products and processes in order to avoid harm to the environment (International Organization for Standardization, 2012).

Discussions of the topic in the Europe Union culminated in the promulgation of the WEEE (European Commission, 2012) and RoHS Directives (European Commission, 2011), specific regulations for electrical and electronic equipments.

The WEEE Directive aims to prioritize the prevention of electronic waste and their reuse, recycling and other forms of recovery in order to reduce the amount of waste to be disposed. It also has the intention to improve the environmental performance of all operators involved in the life cycle of electrical and electronic equipments.

The WEEE Directive establishes the principle of extended producer responsibility; responsibility for financing the collection, treatment, recovery and disposal of electronic waste. Other related topics are the incentive to implement ecodesign, facilitating the disassembly and recovery of materials and compounds from electrical and electronic equipments and measures related to consumer awareness, showing the potential effects on the environment and human health from the presence of hazardous substances in electronics, and ban of disposing electronic waste in regular trash.

The RoHS Directive refers to the restriction and minimum quantity allowed for the use of hazardous substances in electrical and electronic equipments sold in the European Union. Restricted substances in maximum concentration values tolerated by weight in homogenous materials are: - Lead (0.1\%); - Mercury (0.1\%), - Cadmium (0.01\%), - Hexavalent chromium (0.1\%); - Polybrominated biphenyls (PBB) (0.1\%); - Polybrominated diphenyl ethers (PBDE) $(0.1 \%)$.

The restriction of hazardous substances increases the possibilities of recycling of electronic waste and reduces the health risks to workers in the complete life cycle of products, mainly in recycling plants.

The European Directives were the basis for other related regulations over the world citing, for example, "China RoHS", "China WEEE" and "California RoHS", among other regulatory actions in countries like Mexico, Australia, Korea and Japan. In Brazil, the RoHS Directive has not been enacted, but is cited in Instruction $n^{\circ} 01 / 2010$, which establishes the criteria for sustainable procurement of goods, as an item to be considered in the technical specifications for government procurement.

The Brazilian National Policy on Solid Waste (NPSW) establishes general guidelines for waste management. The Law establishes shared responsibility for the lifecycle of products, considering not only the manufactures responsible for the waste management, but also the importers, distributors, retailers, consumers, and holders of urban sanitation services and management.

Among the objectives of NPSW are: the rank of non-generation, reduction, reuse, recycling, solid waste treatment and environmentally sound disposal of waste, the incentive for the adoption of sustainable production and consumption of goods and services, adoption of clean technologies in order to minimize environmental impacts, reduction of waste volume and hazardous substances; integration of collectors of recyclable materials in actions involving shared 
responsibility for the lifecycle of products, incentive to promote sustainable consumption and environmental labeling.

The NPSW obligates the electronic supply chain to structure and implement the reverse logistics system of electrical and electronic equipments. According to NPSW, the reverse logistic is defined as:

Instrument of economic and social development characterized by a set of actions, procedures and means to facilitate the collection and recovery of solid waste to the business sector, to reuse materials in the production cycle or in other production cycle, or other environmentally appropriate destination (BRAZIL, 2010a, p.02)

This requirement will be an instrument to promote new business in the electronics recycling sector and an opportunity to generate jobs and income.

\subsection{Reverse logistics}

In Brazil, the study of processes and models for the reverse flow of logistics is relatively recent and thus the term "reverse logistics" has been employed with widely varying meanings. The approaches tend to move between boundaries that emphasize logistics operation itself, its role in relation to the environment and the competitive advantage that its use can bring to the company.

Rogers \& Tibben-Lembke (1998, p. 2) define reverse logistics as:

The process of planning, implementing, and controlling the efficient, cost effective flow of raw materials, in-process inventory, finished goods and related information from the point of consumption to the point of origin for the purpose of recapturing value or proper disposal.

Leite (2003) introduces the issue in the Brazilian literature and defines reverse logistics as:

\begin{abstract}
[...] The area of logistics business that plans, operates and controls the flow and the logistics information corresponding to the return after-sales products and post-consumption to the production cycle, through the reverse distribution channels, adding value to them of various kinds: economic, ecological, legal, logistics, corporate image, among others (Leite, 2003, p. 16).
\end{abstract}

By the above definition, reverse logistics can be divided into two areas: after-sales reverse logistics and reverse logistics post-consumption. The first is related to planning, control and disposal of goods unused or rarely used, returning to the distribution chain for various reasons, e.g., expiration dates, excess inventory in the channels responsible for the distribution, returns for problems in product guarantee, etc. The second is related to goods at the end of life that can be reuse, recycle or have an appropriate disposal (Leite, 2003).

Differently from reverse logistics after sales that has an economical justification, the logistics post-consumption is also justified by legal and environmental issues.

According to Bowersox \& Closs (2001, p. 51):

Reverse logistics doesn't necessarily mean enhance productivity logistics. However, the reverse movement [...] must be accommodated in logistical planning system [...]. The important point is that the logistics strategy couldn't be formulated without taking into consideration the requirements of reverse logistics.

In Brazil, with the regulation of Brazilian National Policy on Solid Waste, the reverse logistics postconsumption gains visibility, even with its own definition.

According to Barbieri \& Dias (2002), reverse logistics must be designed as an instrument of a proposal for sustainable production and consumption. However, the processes involved in reverse logistics can also bring potential environmental impacts. To consistently evaluate the environmental impacts of reverse logistics it is necessary to have holistic lifecycle thinking.

This type of evaluation can be conducted by the technique of Life Cycle Assessment (LCA), regulated in Brazil, by ABNT NBR ISO 14040 (Associação Brasileira de Normas Técnicas, 2009a) and ABNT NBR ISO 14044 (Associação Brasileira de Normas Técnicas, 2009b). The results of a LCA can help to identify which scenario of reverse logistics has the lower potential environmental impact.

\section{Methodology}

To conduct this study, discarded cell phones were collected in order to define a sample for evaluation. After that, the cell phones were characterized by measuring the mass and the amount of material present in their composition. This approach was essential to identify cell phone materials and their potential impact when sent to recycling facilities.

In a second stage of the study, recyclers were contacted to define the reverse logistics scenarios of cell phones in Brazil. Finally, the proposed scenarios were comparatively evaluated using the technique of LCA with software SimaPro and impact method EPD.

\subsection{Collection and sample characterization}

The campaign to collect cell phones and accessories was performed at Center for Information Technology 
Renato Archer (CTI) during 9 days, from September $27^{\text {th }}$ to October $7^{\text {th }}, 2011$, under the AMBIENTRONIC program.

The AMBIENTRONIC Program aims to create the necessary infrastructure for innovation and qualification of products, processes, management methods, components and materials to adequate the electronic industry to environmental standards and other equally important requirements, adding value to products and meeting the needs of the market for sustainable technologies.

The campaign reached a universe of approximately 850 people.

Public awareness was promoted through emails and posting on the official website. Also, disclosure was made through banners for two days at the $\mathrm{CTl}$ receptions, in a way that the whole audience took notice of the campaign.

CT1 has about 850 employees and 25 individuals made donations, equivalent to $3 \%$. In total, 112 items, 82 cell phones were collected.

In the universe of cell phones collected, 40 samples with different technologies and age was chosen, totaling a mass of $4.942 \mathrm{~kg}$, for disassembly and characterization. The cell phones selected were dismantled, grouped into 3 modules and the weight was recorded. The results of the characterization are shown in Table 1.

\subsection{Reverse logistics scenarios of cell phones in Brazil}

Current scenario of cell phones discarded for recycling in Brazil is shown in Figure 1, as scenario 1.

Differently from scenario 1, in which only the batteries are segregated and recycled in Brazil and the other parts follow to be recycled outside country, the scenario 11 presents the proposed total recycling of electronic waste in Brazil.

\subsection{Proposal of scenarios and life cycle assessment}

The modeling of reverse logistics scenarios of cell phones showed in the following figures (Figures 2 and 3), are based on the values established from the characterization of the sample (Table 1). Basically, the two scenarios differ in the amount of transportation required for reverse logistics and the source of energy used in waste treatment processes.

Scenario 1 considered $10,000 \mathrm{~km}$ for the transportation of the other parts using a cargo ship (see Figure 2 below). For the treatment of the batteries
Table 1. Sample characterization.

\begin{tabular}{lc}
\hline \multicolumn{1}{c}{ Modules } & Percentage (\%) \\
\hline Cell housing & 51 \\
Battery & 27 \\
Printed circuit board (PCB) & 22 \\
\hline
\end{tabular}

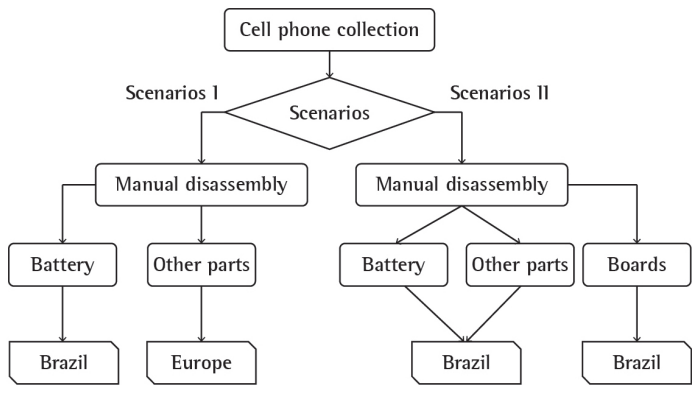

Figure 1. Reverse logistics scenario.

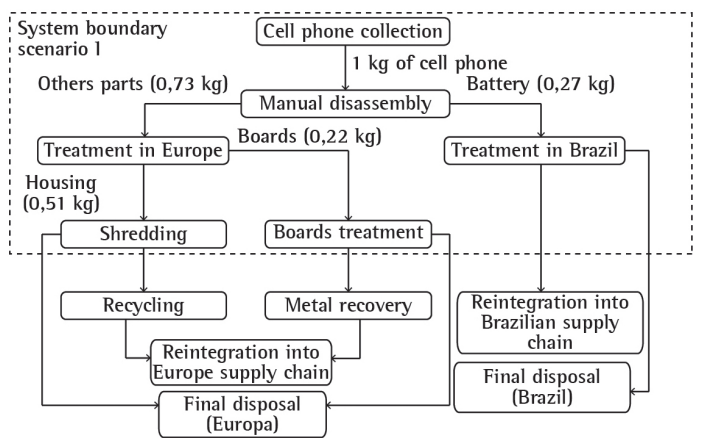

Figure 2. Processes associated with the current scenario (scenario 1) for disposal of cell phones in Brazil.

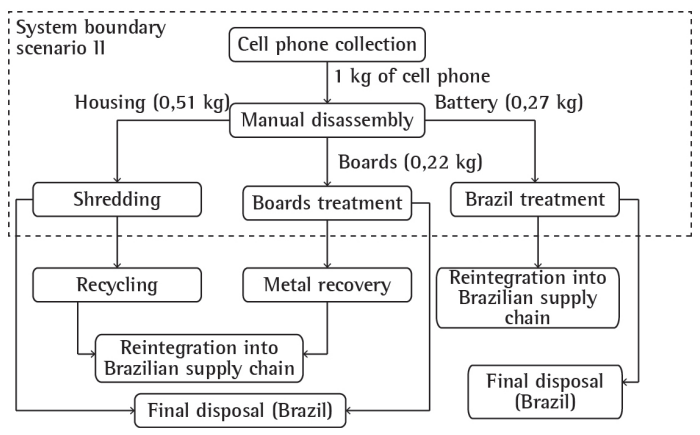

Figure 3. Processes associated with the proposed scenario as an alternative for disposal of cell phones in Brazil (scenario 11).

was considered a regional cargo road transport of $150 \mathrm{~km}$. The energy matrix for recycling in Europe considered in scenario 1 is composed mostly of thermoelectric using mineral coal as fuel source.

In scenario 11 , which portrays the reality of treatment in Brazil, was considered a regional transport of approximately $150 \mathrm{~km}$, using cargo road transport 
for each item segregated (housing, battery and boards). The recycling energy matrix used in scenario 11 is composed mainly by hydropower.

For environmental assessment of the scenarios the technique of Life Cycle Assessment was used, defined as a technique to assess the potential environmental impact of a product or service throughout the lifecycle, from raw materials acquisition, production, use, post-use treatment, recycling and final disposal (Associação Brasileira de Normas Técnicas, 2009a).

Figure 4 shows the flowchart of the technique of LCA according to ABNT NBR ISO 14040 (Associação Brasileira de Normas Técnicas, 2009a):

The quantified goals and scope of the study determine the conditions and characteristics of the study, including the limitations and assumptions adopted and the system boundaries which define the processes included in the assessment.

The inventory analysis is an objective process, based on data to quantify energy and raw materials required, air emissions, emissions to water, solid waste and other environmental emissions incurred during the life cycle of a process, product, activity or service. For this study, international available data was considered in the database ecoinvent (Hischier et al., 2007). The ecoinvent database consists of a set of international data that describes the processes, including resource consumption, auxiliary materials and emissions to air, water and soil (Frischknecht et al., 2007).

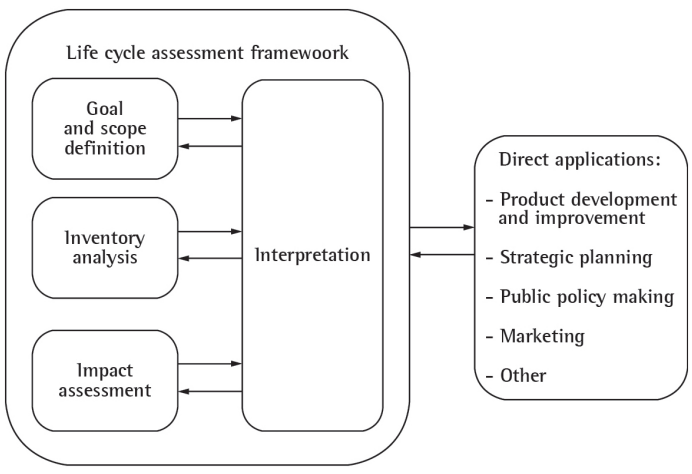

Figure 4. Flowchart of the technique of LCA. Source: Associação Brasileira de Normas Técnicas (2009a).

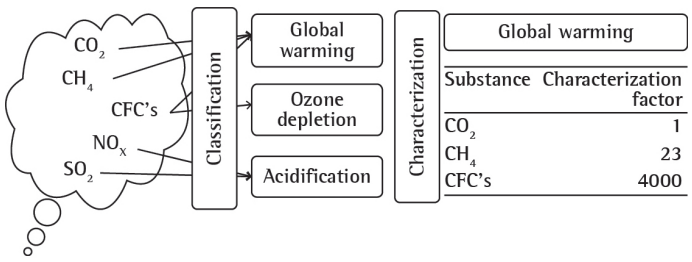

Figure 5. Classification and characterization.
In the stage of impact assessment, data collected in the inventory evaluation are submitted to classification and characterization to determine its potential environmental impact.

The classification is the grouping indicator for each impact category and the characterization refers to the use of factors to determine the potential impact of each substance relative to the category of impact. Figure 5 illustrates the stages of classification and characterization.

The interpretation in LCA is a systematic procedure to identify, qualify, check and evaluate the information of inventory analysis and/or evaluation impacts of a system and present them to meet the application requirements as described in the goals and scope of the study. The interpretation is also a communication process developed to ensure credibility to the results of the more technical phases of LCA, called inventory analysis and impact assessment, so they are both understandable and useful to the decision maker (Associação Brasileira de Normas Técnicas, 2009b).

To assist the management and interpretation of information we used the SimaPro software. This software was developed by the Dutch company PreConsultans, which since 1990 is leading projects of Life Cycle Assessment, developing methodologies, software and consulting. This software supports various databases. The database used for this study, ecoinvent, was developed at the initiative of the Swiss government in order to group different life cycle inventories in a robust and reliable database.

The SimaPro also provides database of impact methods. For this study, we used the method of impact called EPD 2008 to classify and characterize (Figure 5) direct and indirect emissions and consumption from recycling process (e.g. emissions from transportation, diesel combustion, energy production, etc.) in potential environmental impact, ungrouped into categories of environmental impacts outlined in Table 2 below.

\section{Results and discussions}

The evaluation of scenarios using the technique of LCA pointed to a better environmental performance in scenario 11 in which the whole waste treatment is carried out in Brazil, as compared with scenario 1 in which part of the processing is performed in Europe.

Comparatively, the potential for impact reduction is around 60\% for acidification, 35\% for photochemical oxidation, 30\% for eutrophication and 20\% for non-renewable energy. For other categories, the potential for reduction is around 15\%. Figure 6 describes the comparison between scenarios 1 and 11 . 
Table 2. Impact categories, indicators and categories description.

\begin{tabular}{lll}
\multicolumn{1}{c}{ Impact categories } & \multicolumn{1}{c}{ Indicator } & \multicolumn{1}{c}{ Description } \\
\hline Global warming & $\mathrm{kg} \mathrm{CO} 2 \mathrm{eq}$ & Related to the emissions of greenhouse gases \\
Ozone layer depletion & $\mathrm{kg} \mathrm{CFC}-11 \mathrm{eq}$ & Related to the emission of gases that destroy the stratospheric ozone \\
Photochemical oxidation & $\mathrm{kg} \mathrm{C} 2 \mathrm{H} 4 \mathrm{eq}$ & Related to the formation of reactive substances, especially tropospheric ozone \\
Acidification & $\mathrm{kg} \mathrm{SO}$ eq & Related to increase in acidity, resulting from the volatilization of various compounds \\
Eutrophication & $\mathrm{kg} \mathrm{PO4---} \mathrm{eq}$ & Related to nutrient emissions to air, water and soil \\
Non-renewable energy & $\mathrm{MJ} \mathrm{eq}$ & Related to mineral extraction and fossil fuels \\
\hline
\end{tabular}

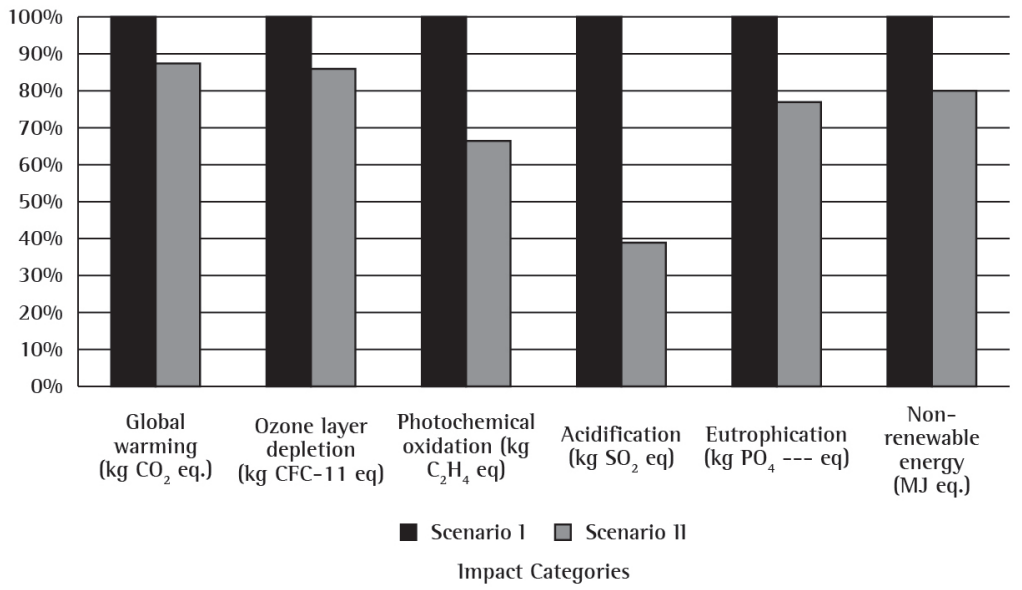

Figure 6. Comparison of potential environmental impact between scenarios 1 and 11.

The electronic waste treatment processes are intensive in energy use. In Brazil, large part of energy come from renewable sources (hydroelectric), making electronic waste treatment processes less harmful to the environment. Another decisive factor for better environmental performance is related to the fact that waste treatment in Brazil demands lower transport and, consequently, less fossil fuel consumption and lower emissions of greenhouse gases.

It is important to point out that if the electronic waste treatment occurs in Brazil, the final waste disposal will need to be grounded in national territory, demanding technological solutions.

But, on the other side, the evaluation of scenarios didn't consider the environmental gains from recycled materials reintegration in the supply chain. The waste treatment performed in Brazil will enable the reintegration of secondary raw materials, resulting in savings of natural resources in Brazil.

\section{Final considerations}

Several initiatives have demonstrated an increased concern for the environmentally sound disposal of electronic waste. The Brazilian National Policy on Solid Waste establishes the requirement to structure and implement reverse logistics for electronic products and their components.

From life cycle perspective, the processes involved in reverse logistics can also bring potential environmental impacts.

This article presented two scenarios to evaluate the reverse logistics of cell phones, using the technique of Life Cycle Assessment. In the first scenario, only the batteries are treated in Brazil, while the other parts/components are treated in Europe. This scenario depicts the current state of cell phone waste treatment in Brazil. In the second scenario was presented a proposal in which all treatment is performed on Brazilian territory.

For modeling scenarios were adopted the same treatment technologies and international data, distinguishing only the amounts of transport and the energy matrix. This approach was adopted due to the lack of a national database.

It is important to note that Brazil doesn't have the technology to recycle entire printed circuit boards, therefore we also considered the technologies used in Europe, changing only the source of energy.

The scenario 11 showed better environmental performance compared to scenario 1, mainly for environmental categories of acidification, 
photochemical oxidation, eutrophication and non-renewable energy. This difference is linked to the energy source and lower fuel consumption due to the transport of electronic waste for treatment.

Scenario 11 also has other benefits not considered in this study, such as the reintegration of secondary raw materials in the supply chain, reducing the pressure on natural resources in Brazil. Furthermore, the performance of the entire reverse logistics in Brazil will enable social and economic gains from the sale of recyclable materials and with generation of employment and income.

\section{References}

Associação Brasileira de Normas Técnicas - ABNT. (2009a). NBR ISO 14040: Gestão Ambiental - Avaliação do ciclo de vida - Princípios e estrutura. Rio de Janeiro: ABNT.

Associação Brasileira de Normas Técnicas - ABNT. (2009b). NBR ISO 14044: Gestão Ambiental - Avaliação do ciclo de vida - Requisitos e orientações. Rio de Janeiro: ABNT.

Basel Convention. (2012). Basel convention on the control of transboundary movements of hazardous wastes and their disposal. UNEP. Retrieved from http://www. basel.int/Portals/4/Basel\%20Convention/docs/text/ BaselConventionText-e.pdf.

Barbieri, J. C., \& Dias, M. (2002). Logística Reversa como instrumento de programas de produção e consumo sustentáveis. Revista Tecnologística, 6(77).

Bowersox, D. J., \& Closs, D. J. (2001). Logística Empresarial: o processo de integração da cadeia de suprimentos. São Paulo: Atlas.

Brasil. (2010a). Institui a Política Nacional de Resíduos Sólidos; altera a Lei $n^{\circ}$ 9.605, de 12 de fevereiro de
1998; e dá outras providências (Lei n 12.305, de 2 de agosto de 2010). Diário Oficial da República Federativa do Brasil.

Brasil. (2010b). Regulamenta a Lei $n^{\circ} 12.305$, de 2 de agosto de 2010, que institui a Política Nacional de Resíduos Sólidos, cria o Comitê Interministerial da Política Nacional de Resíduos Sólidos e o Comitê Orientador para a Implantação dos Sistemas de Logística Reversa, e dá outras providências (Decreto $\mathrm{n}^{\circ} 7404$, de 23 de dezembro de 2010). Diário Oficial da República Federativa do Brasil.

European Commission. (2011). Directive 2011/65/EU of the European Parliament and of the Council of 8 June 2011 on the restriction of the use of certain hazardous substances in electrical and electronic equipment (recast). European Commission.

European Commission. (2012). Directive 2012/19/EU of the European Parliament and of the Council of 4 July 2012 on waste electrical and electronic equipment (recast). European Commission.

Frischknecht, R., Jungbluth, N., Althaus, H. J., Doka, G., Dones, R., Hischier, R., Hellweg, S., Nemecek, T., Rebitzer, G., \& Spielmann, M. (2007). Overview and Methodology. Dübendorf: Swiss Centre for Life Cycle Inventories. Final Report Ecoinvent data, 2.0(1).

Hischier, R., Classen, M., Lehmann, M., \& Scharnhorst, W. (2007). Life cycle inventory of electric and electronic equipment: Use and disposal. Dumbedorf: Swiss centre for life cycle inventories. Ecoinvent Report n. 18, EMPA / Technology and Society.

International Organization For Standardization - 1SO. (2012). Retrieved from www.iso.org.

Leite, P. R. (2003). Logística reversa: meio ambiente e competitividade. São Paulo: Prentice Hall.

Rogers, D. S., \& Tibben-Lembke, R. S. (1998). Going backwards: reverse logistics trends and practices. Reno: University of Nevada, Center for Logistics Management, Reverse Logistics Executive Council. 